\title{
Exploitation of Solar Energy for Ammonium Sulfate Recovery from Anaerobic Digestate of Different Origin
}

\author{
Federico Battista ${ }^{1}$ iD . David Bolzonella ${ }^{1}$ (D)
}

Received: 24 September 2018 / Accepted: 21 January 2019 / Published online: 12 February 2019

(c) The Author(s) 2019

\begin{abstract}
Digestate represents the semi-liquid byproduct of the anaerobic digestion process. It was estimated that 56 Mtonnes of digestate are annually produced only in Europe. Digestate composition depends on the initial total solids (TS) mixture fed to the digester and by its origin (manure, food wastes, agricultural residues, wastewater sludge). Typical values for the different components include a stabilized organic matter content between 20 and $50 \mathrm{~g} / \mathrm{L}$, a good content of nitrogen compounds $(2-8 \mathrm{~g} / \mathrm{kg}$ ) and of phosphorous compounds (up to $3 \mathrm{~g} / \mathrm{kg}$ ). In particular, ammonia presence in digestate is interesting for ammonium sulfate production, a fertilizer which favors plants' growth. Traditional ammonium sulfate synthesis is conducted by stripping followed by sulfuric acid absorption, a process which requires high energy and chemicals consumptions. This work investigates the exploitation of solar energy to evaporate the liquid phase of digestate in a lab-scale greenhouse. Digestate vapors, rich in ammonia, are sent in a Drechsler trap, filled with $38 \% w / w$ sulfuric acid solution, through three solar air fans. The process has been tested on digestates differing for TS content and origin. It emerged that the process is favored by digestates with high ammonia content, as those originated from manure, and a TS content of about $10 \% \mathrm{w} / \mathrm{w}$, which allowed to obtain an ammonium sulfate concentration of about $2 \mathrm{M}$ in the final solution.
\end{abstract}

Keywords Digestate $\cdot$ Carbon sink $\cdot$ Ammonia $\cdot$ Fertilizer $\cdot$ Nitrogen nutrient recovery $\cdot$ Solar energy

\section{Statement of Novelty}

Traditional ammonium sulfate production from digestate requires a previous solid/liquid separation, further polishing of the liquid phase, followed by stripping and absorption in a sulfuric acid solution. This process is characterized by high energy consumption to heat the digestate and by high reagents consumption. This work proposes an innovative and an environmental sustainable way for the ammonium sulfate recovery from digestate, without a previous solid/ liquid separation. In particular, solar energy is exploited to dry the digestate and to recover ammonia vapors, which are sent to a trap containing $\mathrm{H}_{2} \mathrm{SO}_{4}$ to allow the ammonium sulfate production.

Federico Battista

federico.battista@univr.it; federico.battista@gmail.com

1 Department of Biotechnology, University of Verona, Strada Le Grazie 15, 37134 Verona, Italy

\section{Introduction}

In recent years, the growing attention to climate change together with the awareness of raw materials depletion, led to the definition of the "circular economy" vision. This determined the implementation of new environmental laws aimed at the preservation of the environment through the recovery of materials from waste and residual streams. According the "circular economy" model, wastes and byproducts from industrial process, may be further recycled to extract interesting and valuable compounds or used for biofuels production [1]. In this context, anaerobic digestion (AD) became the main biotechnology for the organic matter exploitation and conversion into biogas. Its success is easily explainable considering the possibility to adopt different typologies of biomasses as raw materials (livestock manure, lignocellulosic biomass, food waste, waste activated, sludge, organic fraction of municipal solid waste (OFMSW), fruit and vegetable waste, industrial waste and bio-waste) and by the management simplicity of this technology $[2,3]$. The main byproduct of the $\mathrm{AD}$ process is represented by the digestate, a solid-liquid mixture containing the biomass and the 
non-digested recalcitrant organic materials. These stabilized carbon materials, known as carbon sink, are receiving great attention as it could be able to take $\mathrm{CO}_{2}$ from atmosphere and convert into soil carbon, useful to plants growth [4]. The possibility to sequester an annual amount of $\mathrm{CO}_{2}$ from atmosphere and sequester it in soils for a total increase of $4 \%$ o has been suggested along the Paris COP 21 conferences as a way to compensate the greenhouse gases emissions and to prevent the carbon depletion from the soil. Particularly, digestate is highly enriched in alkaline and alkaline-earth constituents which can contribute significantly to the capture of $\mathrm{CO}_{2}$ by forming carbonates [4]. Digestate is also rich in micro and macronutrients, essentially nitrogen, phosphorous, magnesium and potassium compounds [5, 6]. The quality and the composition of the digestate are influenced by several factors, such as the type of the feedstocks and the operative conditions during the $\mathrm{AD}$ [temperature, hydraulic retention time (HRT), of the organic load rate (OLR) and the solids contents], the presence of inert materials or the content of recalcitrant lignocellulosic materials. In case, of digestate from $\mathrm{AD}$ of animal manure, its characteristics depend on also by the type of the animal (omnivore, ruminant), by the sex, the age and the diet fed to the animal as well as the geographical and the climate conditions [7].

In the circular economy optic, digestate is appreciated for its agronomic use as fertilizer and soil improver. Digestate's chemical composition is able to improve the interaction of the soil-plant systems favoring the increasing of the foliar area and weight of the vegetal, the carbon fixation and the distribution of photo assimilates between the different organs of the plants [8,9]. Despite these advantages, digestates cannot be turn to the soil in their crude form for the release of bad odors, ammonia, and its potential content of no-stabilized organic compounds, pathogens and heavy metals [10]. In addition, the volume of the digestate produced every year is high, about 56 Mtonnes only in Europe and, consequentially, digestate management and transport increase the economic costs of the $\mathrm{AD}$ process $[6,11]$. For these reasons, upgrade post treatments of digestate have been imposed by national and European legislations in order to valorize this output and allow the macro and micronutrients extraction, as proposed by the European Nitrate Directive. It reports the limits of nitrogen compounds in digestate and indicates some processes to extract nitrogen based valuable compounds, such as ammonium sulfate [12]. In general, conventional digestate processing (Fig. 1a) contemplates a mechanical separation of the solid and liquid phases. The solid fraction is rich in recalcitrant organic matter, $\mathrm{Ca}$, $\mathrm{Mg}$, and organic $\mathrm{N}$ and $\mathrm{P}$, while soluble $\mathrm{N}, \mathrm{P}, \mathrm{K}$, ammonia, organics and mineral salts, useful for agronomical scopes, are present in the liquid phase [13]. Liquid phase is usually sent to the ammonia stripping process where ammonia is transferred from liquid to gas phase mostly in packed bed tower. The gas rich in ammonia is then transferred to an air scrubber and treated with sulfuric acid $\left(\mathrm{H}_{2} \mathrm{SO}_{4}\right)$, to form and recover a concentrated solution of ammonium sulfate, $\left(\mathrm{NH}_{4}\right)_{2} \mathrm{SO}_{4}$, a common commercial fertilizer $[6,14]$. This process is characterized by high energy consumption to heat the digestate in the stripper till to $80{ }^{\circ} \mathrm{C}$, and by high reagents consumption: $\mathrm{NaOH}$ to increase $\mathrm{pH}$ before stripping and $\mathrm{H}_{2} \mathrm{SO}_{4}$ during the process $[11,15]$.

The aim of this work is to demonstrate the application of an environmental sustainable way for the ammonium sulfate recovery from digestate in order to reduce the OPEX and CAPEX costs. Solar energy was already tested for the mere digestate drying in different greenhouses in Germany [16] especially in the field of sludge management in the wastewater sector. This work had the ambitious to exploit the solar energy to favor the digestate drying and also the ammonia recover from the liquid phase of digestate (Fig. 1b). Compared to the traditional process, this work does not include the solid/liquid separation of digestate's phases. Different digestate typologies, differing for the substrates fed to the bioreactor (OFMSW, agricultural residues, civil sewage activated sludge) and for the total solid (TS) content (wet, semi-dry, dry fermentation) have been located
Fig. 1 Differences between traditional ammonia recovery (a) and the proposal of this study (b). a Conventional ammonia recovery from digestate. $\mathbf{b}$ Innovative ammonia recovery (this study)

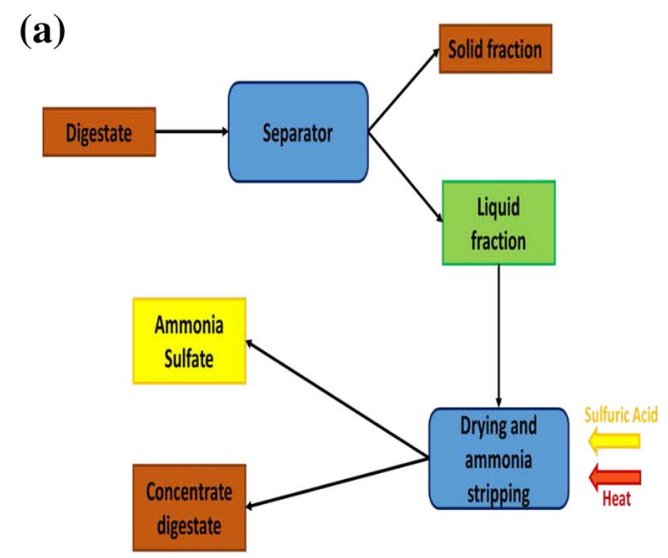

(b)

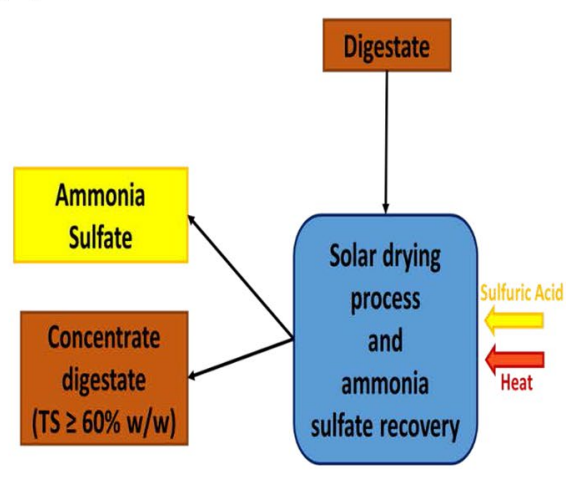


in a transparent greenhouse, exposed to sunlight. Ammonia vapors from digestate have been sent to a Drechsler trap, a bottle provided with porous material filling to favor contact between sulfuric acid solution $(38 \% w / w)$ and digestate's vapors. Digestate drying through solar energy can represent a good opportunity for all the hot climate countries where solar irradiation is available all the yearlong (South Mediterranean regions, Arabian Peninsula, equatorial and tropical countries, like Brazil and India).

\section{Materials and Methods}

\section{The Choice of the Digestates}

The ammonium sulfate recovery was tested on different types of digestate to determine how the chemical and physical characteristics and the operational conditions can affect the process. In particular, four digestates of different origin were chosen, taking into account the most common substrates (agricultural, civil sewage activated sludge and OFMSW) and the TS content usually adopted by AD. The HRT of the digestates were longer for the agricultural digestates, having higher TS content (HRT $=70$ days), and lower for OFMSW and civil activated sludge (HRT $=25$ days).

The following four digestates were considered in this study:

i. Agricultural digestate at wet condition (ADWC), which derived from a biogas plant treating a mixture of bovine manure, chicken manure and rice straw and operating at mesophilic conditions in wet conditions (TS content after AD of about $8 \% \mathrm{w} / \mathrm{w}$ );

ii. Agricultural digestate at dry condition (ADDC), which derived from a biogas plant treating a mixture of bovine manure, chicken manure and rice straw and operating at mesophilic conditions in dry conditions (TS content after $\mathrm{AD}$ of about $18 \%$ w/w);

iii. Civil wastewater sludge (CWS) from a digester treating a mixture of primary and secondary civil sludge at mesophilic condition. The TS content after the $\mathrm{AD}$ was of about $2.50 \% \mathrm{w} / \mathrm{w}$;

iv. OFMSW digestate from a reactor working at mesophilic condition. The TS content of digestate after AD was of about $6.00 \% \mathrm{w} / \mathrm{w}$.

All the digestates were produced in full scale plants in real conditions.

ADWC and ADDC digestates were obtained from two different reactors working at wet and dry conditions, respectively, both located at Isola della Scala (Italy). CSAS originated from an urban wastewater plant in Verona (Italy), while OFMSW digestate derived from a plant in Asigliano Veneto (Italy).

\section{The Greenhouse for the Drying of Digestate}

Figure 2 shows the lab scale transparent greenhouse for the drying of digestate. The greenhouse, having the dimensions of $50 \times 40 \times 30 \mathrm{~cm}$, has been exposed at sunlight during summer season in order to have operative temperatures comparable to Sfax (Tunisia) weather conditions, where it is supposed to realize the scale-up of the present research work.

The digestate drying was assured by three air fans (Digiflex Solar Powered Cooling Fan) which had a diameter of $6 \mathrm{~cm}$ and a solar panel $(5 \times 6 \mathrm{~cm})$. Ammonia vapors from digestate have been sent to a Drechsler trap, a bottle provided with porous material filling to favor contact between sulfuric acid solution $(38 \% w / w)$ and digestate's vapors [14]. The porous material was constituted by borosilicate glass with porous dimensions in the range of $100-160 \mu \mathrm{m}$, which is usually used to gas transfer in a liquid phase. The amount of sulfuric acid solution in Dreshler trap was $0.4 \mathrm{~L}$. The greenhouse presents also a section shrinkage to increase speed of vapors towards the Drecheler trap. The greenhouse was filled with $10 \mathrm{~L}$ of each digestate and the test was stopped when the TS concentration reached at least the $60 \% \mathrm{w} / \mathrm{w}$. This is the minimal value of TS content after a preliminary drying process required by Italian legislation. Then digestate is further treated to reach a final value of wet content lower to $10 \%$
Fig. 2 The solar greenhouse and its main components

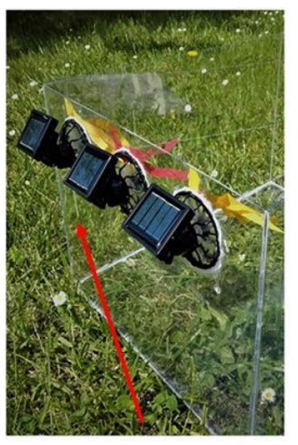

Solar air-fans

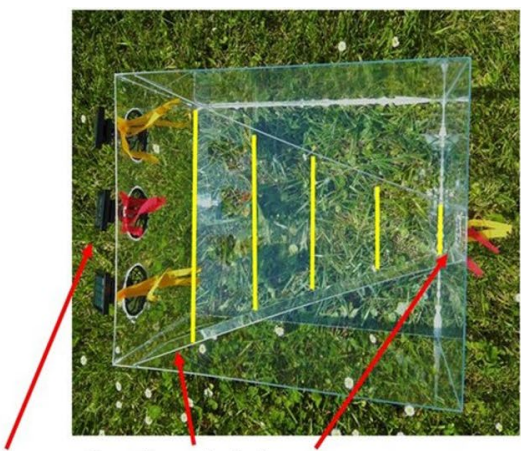

Section shrinkage

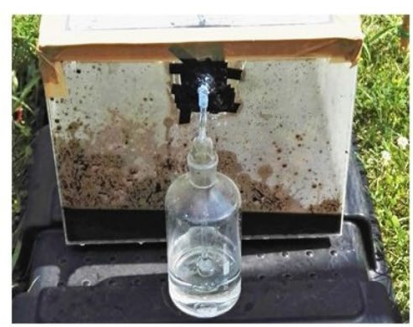

Drechsel trap with $38 \%$ w/w sulfuric acid solution 
[17]. The greenhouse has been located in a quiet zone of the garden of the Department of Biotechnology of the University of Verona (latitude $45^{\circ} 24^{\prime} 09^{\prime \prime} \mathrm{N}$, longitude $10^{\circ} 59^{\prime} 54^{\prime \prime} \mathrm{E}$ ). Verona is characterized by a continental climate with annual average maximum and minimal temperature of $18{ }^{\circ} \mathrm{C}$ and $8{ }^{\circ} \mathrm{C}$, respectively. The rainfalls are distributed along all the year, with a major concentration in the hottest months. In summer the maximum and minimal temperatures are $29{ }^{\circ} \mathrm{C}$ and $23{ }^{\circ} \mathrm{C}$, respectively, which are suitable to simulate the weather conditions in South Mediterranean area, and in equatorial and tropical regions [18].

\section{The Evaluation of the Test Performances}

The performances of the test were evaluated essentially taking into account the following factors: (i) the concentration of ammonium sulfate solution recovered within the Drecheler trap from each digestate; (ii) the yield of the ammonia recovery expressed as amount gone in the reaction with sulfuric acid and recovered as ammonium sulfate (n) and (iii) the time required to reach the $60 \% \mathrm{w} / \mathrm{w}$ TS concentration $\left(\mathrm{t}_{60}\right)$. In particular $\eta$ was expressed as: was not possible. For this reasons, the averages of the maximum and minimum temperatures recorded along the test period, the numbers of raining days, were also indicated next to the duration time of each test. It is fundamental to underline that rainy days negatively influence not only the digestate drying but also the solar air working, favoring the escape of rich ammonia vapors outside the greenhouse.

The drying of each digestate typology was tested in duplicate in order to verify its repeatability and reduce the weather conditions' influence.

Nitrogen mass balance has been also performed to highlight the nitrogen losses along the process. Nitrogen losses are mainly due to ammonia vapors, which escaped from the greenhouse during night or cloudy days when solar irradiation does not assure the working of air fans. The nitrogen losses $\left(\mathrm{L}_{\mathrm{N}}\right)$ have been evaluated considering the nitrogen concentration of digestates before and after the drying process (TKN values in Table 1) and the ammonia recovered as ammonium sulfate, whose calculation has been described above. $\mathrm{L}_{\mathrm{N}}$ has been expressed as percentage refereed to the initial nitrogen (TKN) content in the digestate.

$\eta(\%)=100 \frac{\text { amount of ammonia gone in reaction with sulfuric acid and recovered as ammonium sulfate }(\mathrm{g})}{\text { amount of ammonia initially present in digestate }(\mathrm{g})}$

where the amount of ammonia gone in reaction with sulfuric acid and recovered as ammonium sulfate was calculated considering the ammonium sulfate concentration $(\mathrm{M})$ in the Drechsler trap and the molar coefficients of reaction 1.

$2 \mathrm{NH}_{3}+\mathrm{H}_{2} \mathrm{SO}_{4} \rightarrow\left(\mathrm{NH}_{4}\right)_{2} \mathrm{SO}_{4}$

(reaction 1)

$\mathrm{t}_{60}$ parameter is clearly influenced by the weather conditions, such as outside temperatures during tests and the numbers of cloudy sky or raining days, when solar exposition

\section{Analytic Methods}

Several parameters were considered for the characterization of each digestate at the beginning and at the end of the test: $\mathrm{pH}$, total COD, TS, VS, and the concentrations of total nitrogen compounds (TKN), ammonia and total phosphorus (TP). TS, VS, COD, TKN, ammonia and TP were determined using the standard methods described in the scientific literature [19]. To determine the ammonium sulfate content in the

Table 1 The characterization of the digestates before (In) and after (Out) the solar drying

\begin{tabular}{lrlrlrlrl}
\hline & \multicolumn{1}{c}{ ADWC in } & ADWC out & \multicolumn{1}{c}{ ADDC in } & ADDC out & CWS in & CWS out & OFMSW in & OFMSW out \\
\hline $\mathrm{pH}$ & $8.53 \pm 0.02$ & Not measured & $8.02 \pm 0.01$ & Not measured & $7.39 \pm 0.03$ & Not measured & $7.62 \pm 0.02$ & Not measured \\
$\mathrm{TS}(\% w / w)$ & $9.06 \pm 0.08$ & $67.69 \pm 6.25$ & $18.80 \pm 0.53$ & $75.32 \pm 1.25$ & $2.58 \pm 0.01$ & $60.85 \pm 1.56$ & $6.19 \pm 0.26$ & $85.17 \pm 3.30$ \\
$\mathrm{VS}(\% \mathrm{w} / \mathrm{w})$ & $6.16 \pm 0.57$ & $45.20 \pm 5.26$ & $13.62 \pm 1.26$ & $53.56 \pm 1.43$ & $1.88 \pm 0.03$ & $42.70 \pm 1.87$ & $3.71 \pm 0.50$ & $47.87 \pm 2.22$ \\
$\mathrm{VS}(\% \mathrm{TS})$ & $67.99 \pm 2.23$ & $67.03 \pm 2.61$ & $72.44 \pm 1.95$ & $71.10 \pm 0.94$ & $73.06 \pm 0.64$ & $70.17 \pm 0.69$ & $59.92 \pm 0.86$ & $55.56 \pm 1.02$ \\
$\mathrm{COD}(\mathrm{g} / \mathrm{kg})$ & $45.24 \pm 2.19$ & $37.61 \pm 2.61$ & $53.75 \pm 3.60$ & $49.57 \pm 1.37$ & $20.61 \pm 1.65$ & $16.42 \pm 1.16$ & $58.39 \pm 1.72$ & $42.23 \pm 3.14$ \\
$\mathrm{TKN}(\mathrm{g} / \mathrm{kg})$ & $7.18 \pm 0.40$ & $2.52 \pm 0.26$ & $5.03 \pm 0.79$ & $3.14 \pm 0.15$ & $0.71 \pm 0.08$ & $0.41 \pm 0.07$ & $3.21 \pm 0.62$ & $1.27 \pm 0.21$ \\
$\mathrm{NH}_{4}^{+}(\mathrm{g} / \mathrm{kg})$ & $6.05 \pm 0.22$ & $1.60 \pm 0.53$ & $3.81 \pm 0.43$ & $1.82 \pm 0.05$ & $0.33 \pm 0.02$ & $0.09 \pm 0.01$ & $1.91 \pm 0.35$ & $0.31 \pm 0.07$ \\
$\mathrm{NH}_{4}^{+} / \mathrm{TKN}(\%)$ & $84.26 \pm 2.62$ & $63.49 \pm 1.60$ & $75.74 \pm 3.90$ & $57.95 \pm 1.64$ & $46.47 \pm 2.97$ & $21.95 \pm 1.60$ & $59.50 \pm 2.49$ & $24.41 \pm 3.15$ \\
$\mathrm{P}(\mathrm{mg} / \mathrm{kg})$ & $2.97 \pm 0.10$ & $2.01 \pm 0.02$ & $2.75 \pm 0.35$ & $1.89 \pm 0.26$ & $0.43 \pm 0.03$ & $0.18 \pm 0.02$ & $1.98 \pm 0.17$ & $1.03 \pm 0.19$ \\
\hline
\end{tabular}

The COD, TKN, NH4+ and $\mathrm{P}$ concentrations are referred to raw sample

ADWC: agricultural digestate at wet condition; ADDC: agricultural digestate at dry condition; CWS: civil wastewater sludge; OFMSW: organic fraction municipal solid wastes 
Drechsler trap solution, the back titration method has been adopted. In particular, this technique is based on destruction of ammonia salts and the ammonia evaporation from solution by sodium hydroxide addition (reaction 2) until to reach a $\mathrm{pH}$ of 11 , when all ammonia compounds pass in gaseous phase, which has been distilled by VELP UDK 159 distillation unit [20]. Then, 2-3 drops of phenolphthalein are added to the solution, which is then titrated with hydrochloric acid solution $(0.1 \mathrm{~N})$ (reaction 3), until the red color is lost.

$\left(\mathrm{NH}_{4}\right)_{2} \mathrm{SO}_{4(\mathrm{aq})}+\mathrm{NaOH}_{(\mathrm{aq})} \rightarrow \mathrm{NH}_{3(\mathrm{~g})}+\mathrm{Na}_{2} \mathrm{SO}_{4(\mathrm{aq})}+2 \mathrm{H}_{2} \mathrm{O}_{(\mathrm{l})}$

(reaction 2)

$\mathrm{NaOH}+\mathrm{HCl} \rightarrow \mathrm{NaCl}+\mathrm{H}_{2} \mathrm{O}$

(reaction 3)

\section{Results and Discussions}

\section{Digestate Characteristics Before Solar Drying}

\section{$\mathrm{pH}, \mathrm{TS}$ and VS Concentrations}

Table 1 summarizes the main parameters used for the characterization of digestates.

The $\mathrm{pH}$ values were all neutral or slightly basic at the beginning of the tests. These values indicate the good performance of the $\mathrm{AD}$ process. Before feeding the reactor, organic substrates are often characterized by slightly acidic $\mathrm{pH}$, as effect of the natural hydrolytic process. Thus, some basic pretreatments or the addition of ammonia rich digestate to the substrates are usually operated before the beginning of $\mathrm{AD}$ [21]. The first steps of the $\mathrm{AD}$, the hydrolysis and the acidogenesis, are characterized by the organic matter degradation in volatile fatty acids (VFAs) which contribute to $\mathrm{pH}$ drop. VFAs are then used in the following methanogenic phase for the biogas production, with a consequent $\mathrm{pH}$ increasing towards neutral or slightly basic values [11, 22]. Table 1 shows the existing correlation between $\mathrm{pH}$ and the ammonia concentration in the digestate: a higher $\mathrm{pH}$ is also due by a higher ammonia concentration, as in the case of ADWC and ADDC. This property is exploited when AD is conducted in two stages, consisting in the separation of acidogenic phase from methanogenic one in two different reactors. In this case, rich ammonia digestate from methanogenic reactor is partially recirculated in the acidogenic phase to avoid a $\mathrm{pH}$ decreasing towards inhibiting values [2].

As previously commented, the digestates have been chosen to differ for typologies of wastes treated along the $\mathrm{AD}$ and for the different TS content. In this way, the drying performance within the greenhouse has been evaluated at different initial operative conditions.

Different TS contents mean, consequentially, different initial VS levels. It is interesting to observe that the VS/TS ratio is around $70 \%$ for $\mathrm{ADWC}$, $\mathrm{ADDC}$ and CWS before the solar drying process. These high values can be explained considering that food and agricultural wastes, fed to AD process, are characterized by high organic matter (VS) concentration, usually between 50 and $120 \mathrm{~g} / \mathrm{kg}$ of fresh matter, and a very low concentration of inert materials [23, 24]. As a consequence, the VS/TS ratio before the AD process is around $90-95 \%$ [24]. The VS/TS ratio of the digestates is influenced by the lignocellulosic matter concentration, known to be more recalcitrant and less transformable into biogas than carbohydrates, fats and proteins, and also by the operative conditions of AD, such as the HRT, the OLR and the temperature [25]. In the specific case, ADWC and ADDC were rich of lignocellulosic matrix because bovine and chicken manures were mixed with rice straws' fibers, which contributed to have a relative high of VS/TS ratio (70\%).

CWS digestate is characterized by low TS content and consequentially of organic matter (Table 1). Low content of organic matter is common in activated sewage sludge and can inhibit denitrification process, which is included in Wastewater Treatment Plants (WWTP). Denitrification is conducted by anoxic microorganisms which require higher organic substrates (VS) for their metabolic activities [15]. Thus, AD is commonly employed as a method that provides the environmental benefits of reducing sludge, to generate biogas but also to supply simple carbon compounds for denitrification [26]. The only digestate characterized by lower VS/TS ratio was the OFMSW one (59.9\%), as consequence of its composition including plastic or glass fragments $(<2 \mathrm{~mm}$ ), from bags used to collect wastes or improperly introduced by people [27].

\section{COD, Nitrogen and Phosphorus Concentrations}

The amounts of carbon and nitrogen are fundamental to define a soil amendment. As reported by COD values in Table 1, the organic matter concentration in digestate vary according the wastes typology: CWS digestate had a COD concentration of about $20 \mathrm{~g} / \mathrm{L}$, while ADDC and OFMSW digestates were about 55-60 g/L, before the solar drying process. These values depend on TS and VS concentrations: a major dilution of the sludge corresponds clearly to a lower COD level.

Among the organic carbon, cellulosic materials, just partially degraded during $\mathrm{AD}$, are particularly interesting for agronomic use. Their degradation is slow, as effect of their chemical complexity, and this allows supplying carbon sources to soil for humus built-up in a gradual way, avoiding the possibility of soil acidification [28].

Regarding the nitrogen compounds, Kirchmann et al. [29] remarked that, rather than the total concentration (TKN), is the balance between organic and mineral (ammonium) to influence the agronomic use of digestate. The higher the 
share of ammonium, the higher the efficiency of the digestate as a $\mathrm{N}$-fertilizer [6]. In fact, ammonium is immediately available to be adsorbed and used by the plants; thus high $\mathrm{NH}_{4}{ }^{+}$/TKN ratio is preferable because it reduces the volume needed for spreading on fields [30]. Ammonium derives from the biological degradation of nitrogenous matter, mostly present in the form of proteins and urea [31]. Typical protein rich substrates are manure and food wastes $[6,7]$. It allows to explain the high content of TKN and ammonia in ADWC, respectively of 7.2 and $6.1 \mathrm{~g} / \mathrm{kg}$, in ADDC which had respectively 5.0 and $3.8 \mathrm{~g} / \mathrm{kg}$ and in OFMSW digestate which recorded lower but still significant nitrogen and ammonia concentrations of 3.2 and $1.9 \mathrm{~g} / \mathrm{kg}$, respectively. Instead CWS was characterized by low nitrogen and ammonia concentrations as effects of the low TS concentration.

Lastly, some considerations for phosphorous content in digestate. Phosphorus is a non-substitutable plant nutrient and therefore essential for agriculture. Phosphorous recovery and its conversion in fertilizer, such as struvite, is becoming particularly interesting in agronomic field [32]. The trend of the total phosphorous content among the considered digestate is the same as nitrogen and ammonia trends: higher
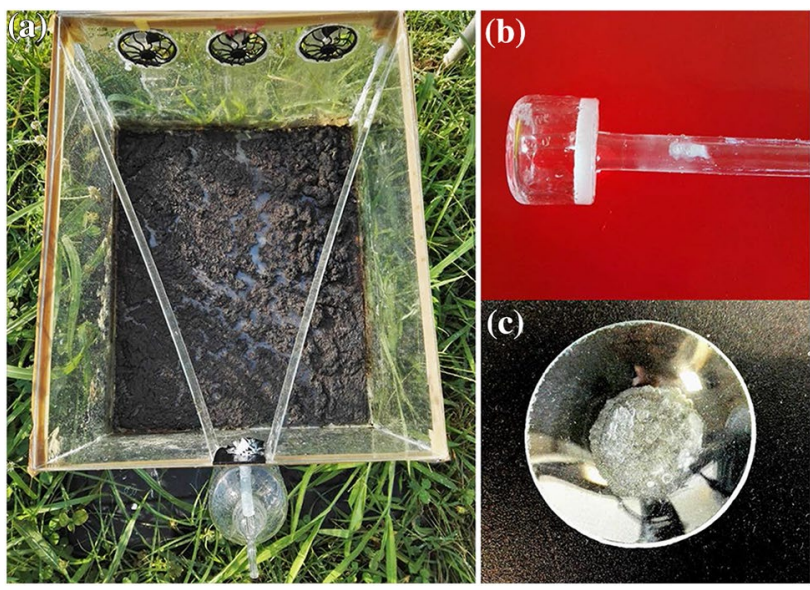

Fig. 3 The digestate at the end of the solar drying (a), the ammonium sulfate spontaneously crystalized within the trap (b) and ammonium sulfate recovered after solvent evaporation (c) for ADWC, ADDC and OFMSW with a concentration of $2.97,2.75$ and $1.98 \mathrm{mg} / \mathrm{kg}$, respectively, low for CWS with $0.43 \mathrm{mg} / \mathrm{kg}$.

\section{Ammonium Sulfate Recovery from Digestate}

Figure 3 shows the effect of solar drying on digestate (Fig. 3a), the spontaneous formation of white ammonium sulfate crystals on a component of the Drechsler trap (Fig. 3b) and the ammonium sulfate solution recovered after a slow solvent evaporation at $60{ }^{\circ} \mathrm{C}$ (Fig. 3c).

Table 2 summarizes the concentrations of ammonium sulfate solutions in the Drecheler trap, the yield of ammonia gone in reaction with sulfuric acid $(\eta)$, the time needed to reach the TS concentration of $60 \% w / w\left(\mathrm{t}_{60}\right)$ and the weather conditions for the different tests.

ADWC test reached the best ammonium sulfate concentration and the ammonia recovery yield $(\eta)$ respectively of $2.02 \mathrm{M}$ and $45.41 \%$. The performance of ADDC were lower with a concentration of ammonium sulfate in the trap of $1.04 \mathrm{M}$ and $\mathrm{a} \eta$ of $37.11 \%$. These first two results allows a first consideration: even if these tests had the same wastes typology, the TS content influenced the final performance. Ammonium, in fact, is a soluble compounds and, thus, mostly present in the liquid fraction of digestate [33]. So, the lower ammonia concentration of ADDC than ADWC (Table 1) may be due to the lower water amount in digestate. In addition, Ukwuani and Tao [20] demonstrated that higher solids concentration, as happens in ADDC, favors ammonia adsorption to the substrates, impeding its dissociation and the transfer to the vapor phase. This theory found confirmation in the ammonia concentrations of digestate at the end of the tests, which were of 1.60 and $1.82 \mathrm{~g} / \mathrm{kg}$ for ADWC and ADDC, respectively. The ammonium sulfate solution's concentration from OFMSW digestate was low $(0.53 \mathrm{M})$ but the correspondent $\eta$ is slightly higher than ADDC, of $37.74 \%$. These results are only apparently contradictory: the low ammonium sulfate concentration is essentially due to the lower ammonia concentration in OFMSW digestate at the beginning of the test, but the ammonia recovery yield was the same as ADDC. Lastly, no ammonium sulfate recovery
Table 2 Factors summarizing the solar drying performances of digestates

\begin{tabular}{lrrrr}
\hline & \multicolumn{1}{l}{ ADWC } & \multicolumn{1}{l}{ ADDC } & \multicolumn{1}{l}{ CWS } & \multicolumn{1}{c}{ OFMSW } \\
\hline $\begin{array}{l}\left.\mathrm{NH}_{4}\right)_{2} \mathrm{SO}_{4} \text { concentration in } \\
\quad \text { Drechsler trap }(\mathrm{M})\end{array}$ & $2.02 \pm 0.27$ & $1.04 \pm 0.31$ & $0.00 \pm 0.00$ & $0.53 \pm 0.11$ \\
$\mathrm{\eta} \mathrm{NH}_{3}(\%)$ & $45.41 \pm 6.06$ & $37.12 \pm 11.06$ & $0.00 \pm 0.00$ & $37.74 \pm 7.83$ \\
$\mathrm{~L}_{\mathrm{N}}(\%)$ & $26.70 \pm 3.07$ & $37.56 \pm 3.92$ & $42.25 \pm 1.63$ & $37.94 \pm 2.18$ \\
$\mathrm{t}_{60}$ (days) & $10.50 \pm 0.50$ & $12.00 \pm 2.00$ & $6.50 \pm 1.00$ & $9.50 \pm 1.00$ \\
$\mathrm{~T}$ max average along the test $\left({ }^{\circ} \mathrm{C}\right)$ & $27.45 \pm 1.44$ & $28.50 \pm 1.38$ & $31.11 \pm 2.93$ & $33.50 \pm 1.18$ \\
T min average along the test $\left({ }^{\circ} \mathrm{C}\right)$ & $18.63 \pm 1.96$ & $19.33 \pm 1.92$ & $20.33 \pm 2.00$ & $22.50 \pm 1.35$ \\
Numbers of rainy days & $4.00 \pm 0.00$ & $5.00 \pm 1.00$ & $1.00 \pm 0.00$ & $2.00 \pm 0.50$ \\
\hline
\end{tabular}


in Drechsler trap was obtained from CWS test, whose initial ammonia concentration was just of $0.33 \mathrm{~g} / \mathrm{kg}$, not enough to assure a minimum driving force needed to assure the contact from ammonia vapors and the liquid sulfuric acid solution in the Drechsler trap. Vapors temperature and initial ammonia concentration in digestate are the main factors which favor the driving force, as discussed by Green and Perry [34]. The previous considerations demonstrate, from one hand, that higher TS assures the ammonia transfer to vapor phase with a better ammonium sulfate recovery in the Drechsler trap. From the other hand, a too high TS content favor the ammonia adsorption, decreasing the process's performances. Based on these tests' results, the optimal TS concentration was of about $10 \% \mathrm{w} / \mathrm{w}$.

The residence time of digestate in the greenhouse represents an important parameter in the optic of a scale-up of the process. It is easily understandable that a lower duration of the process corresponds to higher amount of digestate processed, higher ammonium sulfate recovery and thus economic gains. All the tests reached the $60 \% \mathrm{w} / \mathrm{w}$ TS concentration in less than 2 weeks $\left(\mathrm{t}_{60}\right.$ values in Table 2$)$. The parameter was strongly influenced by the weather conditions: ADWC and ADDC required longer time (10.5 and 12.0 days, respectively) than CWS and OFMSW (6.50 and 9.50 days). The temperatures corresponding to ADWC and ADDC tests were of about $27-28{ }^{\circ} \mathrm{C}$ in the maximum values and $18-19{ }^{\circ} \mathrm{C}$ in the minimum ones, while rainy days, with a partial or none solar irradiation, were 4-5. On the contrary, CWS and OFMSW digestates beneficed of better weather conditions with just 1 and 2 rainy days, respectively for CWS and OFMSW tests, and higher temperature (over $30{ }^{\circ} \mathrm{C}$ for the maximum values). These latter conditions are closer to summer temperatures in Sfax (Tunisia) [35], where a scaleup of the process is supposed to be realized. In addition, $\mathrm{t}_{60}$ parameter is also influenced by the initial TS concentration.

Almost all the tests (ADWC, ADDC and OFMSW) manifested the formation of a crust layer, as effect of the water evaporation just from the surface of digestate, which slowed down the evaporation kinetic. For this reason, it was occasionally necessary to shuffle the digestate in the greenhouse, to break the crust layer and allow the underlying aqueous phase exposition to solar irradiation. CWS test was the test with none crust layer formation, probably for the very low TS content (about $2.50 \% \mathrm{w} / \mathrm{w}$ ), resulting the test with the lower $\mathrm{t}_{60}$.

Nitrogen losses $\left(\mathrm{L}_{\mathrm{N}}\right.$, Table 2$)$ is another parameter to evaluate the process' performances. As already commented, $\mathrm{L}_{\mathrm{N}}$ depended on the ammonium sulfate recovered in the solution and on the numbers of cloudy or rainy days which reduced the solar irradiation, stopping the solar air fans. Clearly $\mathrm{L}_{\mathrm{N}}$ was lower for ADWC $(26.70 \%)$ which reached higher ammonium sulfate recovery. It became progressively higher for ADDC, OFMSW (about 38\%) which had similar ammonium sulfate yield, until to reach the maximum value of about $42 \%$ with CWS where no ammonium sulfate was recovered. It is important to remark that ADWC and ADDC tests were conditioned by higher rainy days (Table 2) which, probably favored the ammonia vapors escape from the greenhouse. Thus, these tests could have reached higher ammonium sulfate recovery' yield $\left(\mathrm{n} \mathrm{NH}_{3}\right)$, reducing the nitrogen lossed $\left(\mathrm{L}_{\mathrm{N}}\right)$.

Table 1 reports the characteristics of the dewatered digestates too. It is possible to note that the VS/TS ratio is not influenced by the solar irradiation, meaning that the aerobic degradation phenomena did not occurred and that substrates were well stabilized by AD. Also the phosphorous compounds' concentration kept constant after the dying process, while nitrogen compounds saw a decreasing, as consequence of ammonia evaporation. In fact, $\mathrm{NH}_{4}^{+} / \mathrm{TKN}$ ratio showed a reduction of about $50-55 \%$ in all the tests, demonstrating that organic nitrogen was almost not involved by the process and the remaining ammonia was probably absorbed by the substrates, as previously commented. The only exception, having a lower reduction of $\mathrm{NH}_{4}^{+} / \mathrm{TKN}$, was ADDC where the ammonia adsorption phenomena was more intense for the high TS content, as already discussed.

The presence of stabilized and labile organic matter, of low ammonia concentrations, good organic nitrogen and phosphorous concentrations make these dewatered digestates interesting as potential soil improvers and to active soil biology [36, 37].

\section{Conclusions}

This research work investigated the possibility to exploiting solar energy for digestate drying and ammonium sulfate recovery. Different digestates were located in a transparent greenhouse exposed to solar irradiation, provided by three solar air fans to favor the aqueous phase evaporation and the ammonia rich vapors' addressing to a Drechsler trap filled with $38 \% \mathrm{w} / \mathrm{w}$ sulfuric acid solution. It emerged that the drying digestate is clearly influenced by weather conditions (temperature and sunny days) but also by the TS content of digestate. In fact, a TS concentration higher than 5\% w/w induced to a superficial crust layer which prevented the below aqueous phase evaporation and required an occasionally mixing of digestate. In addition a too high TS (15-20\% TS $w / w$ ) content favored ammonia adsorption on the substrates, reducing the amount potentially recovered and converted in ammonium sulfate. Instead, a low TS content, as in activated sewage sludge digestate, was neither convenient because it meant, consequentially, low initial ammonia concentration too. A good compromise resulted to be a TS concentration of about $10 \% \mathrm{w} / \mathrm{w}$. Regarding the ammonium sulfate recovery, it was essentially influenced by the origin 
of digestate. In particular, high protein substrates, rich in nitrogen and ammonia, such as animal manure and food wastes resulted in good ammonium sulfate recovery, with a concentration in the Drechsler trap of about $2 \mathrm{M}$. On the contrary, digestate rich in inert materials, as OFMSW, or poor TS content, as activated civil sludge, emerged in low or null ammonium sulfate recovery.

The positive results of this study encourage a scale-up of the project with the realization of a new greenhouse provided also by a floor grating to better separate liquid phase of digestate, increasing the drying speed of the process. In addition, the solar fans will be provided by a solar battery to assure a continuous working of the fans, even when solar irradiation misses.

Acknowledgements This research is financed by Eranet Med Biogasmena (Project Number 72-026), which contemplates the optimization of technologies for biogas production and nutrients recovery from digestate in the MENA (Middle East and North Africa) regions.

Open Access This article is distributed under the terms of the Creative Commons Attribution 4.0 International License (http://creativeco mmons.org/licenses/by/4.0/), which permits unrestricted use, distribution, and reproduction in any medium, provided you give appropriate credit to the original author(s) and the source, provide a link to the Creative Commons license, and indicate if changes were made.

\section{References}

1. Blomsma, F., Brennan, G.: The emergence of circular economy: a new framing around prolonging resource productivity. J. Ind. Ecol. 21, 603-614 (2017)

2. Bolzonella, D., Battista, F., Cavinato, C., Gottardo, M., Micolucci, F., Lyberatos, G., Pavan, P.: Recent developments in biohythane production from household food wastes: a review. Bioresour. Technol. 257, 311-319 (2018)

3. Akhiar, A., Battimelli, A., Torrijos, M., Carrere, H.: Comprehensive characterization of the liquid fraction of digestates from fullscale anaerobic co-digestion. Waste Manag. 59, 118-128 (2017)

4. Minasny, B., Malone, B.P., McBratney, A.B., Angers, D.A., Arrouays, D., Chambers, A., Chaplot, V., Chen, Z.C., Cheng, K., Das, B.S., Field, D.J., Gimona, A., Hedley, C.B., Hong, S.Y., Mandal, B., Marchant, B.P., Martin, M., McConkeyb, B.G., Mulder, V.L., O'Rourke, S., Richer-de-Forges, A.C., Odeh, I., Padarian, J., Paustian, K., Pan, G., Poggio, L., Savin, I., Stolbovoy, V., Stockmann, U., Sulaeman, Y., Tsui, C.C., Vågen, T.G., Wesemael, B.V., Winowiecki, L.: Soil carbon 4 per mille. Geoderma 292, 59-86 (2017)

5. Peng, W., Pivato, A.: Sustainable management of digestate from the organic fraction of municipal solid waste and food waste under the concepts of back to earth alternatives and circular economy. Waste Biomass Valorization. (2017). https://doi.org/10.1007/ s12649-017-0071-2

6. Vaneeckhaute, C., Lebuf, V., Michels, E., Belia, E., Vanrolleghem, P.A., Tack, F.M.G., Meers, E.: Nutrient recovery from digestate: systematic technology review and product classification. Waste Biomass Valorization 8, 21-40 (2017)

7. Risberg, K., Cederlund, H., Pell, M., Arthurson, V., Schnürer, A.: Comparative characterization of digestate versus pig slurry and cow manure - chemical composition and effects on soil microbial activity. Waste Manag. 61, 529-538 (2017)

8. Abubaker, J., Risberg, K., Pell, M.: Biogas residues as fertilisers-effects on wheat growth and soil microbial activities. Appl. Energy 99, 126-134 (2012)

9. Iocoli, G.A., Zabaloy, M.C., Pasdevicelli, G., Gómez, M.A.: Use of biogas digestates obtained by anaerobic digestion and codigestion as fertilizers: characterization, soil biological activity and growth dynamic of Lactuca sativa L. Sci. Total Environ. 647, 11-19 (2019)

10. Wojnowska-Baryła, I., Bernat, K., Sartowska, S.: Biological stability of multi-component agri-food digestates and postdigestates. Waste Manag. 77, 140-146 (2018)

11. Tampio, E., Salo, T., Rintala, J.: Agronomic characteristics of five different urban waste digestates. J. Environ. Manage. 169, 293-302 (2016)

12. Pedrazzi, S., Allesina, G., Belló, T., Rinaldini, C.A., Tartarini, P.: Digestate as biofuel in domestic furnaces. Fuel Process. Technol. 130, 172-178 (2015)

13. Hjorth, M., Christensen, K.V., Christensen, M.L., Sommer, S.G.: Solid-liquid separation of animal slurry in theory and practice. A review. Agron. Sustain. Dev. 30(1), 153-180 (2010)

14. Stutzenstein, P., Bacher, M., Rosenau, T., Pfeifer, C.: Optimization of nutrient and carbon recovery from anaerobic digestate via hydrothermal carbonization and investigation of the influence of the process parameters. Waste Biomass Valorization $\mathbf{9}$, 1303-1318 (2018)

15. Bolzonella, D., Fatone, F., Gottardo, M., Frison, N.: Nutrients recovery from anaerobic digestate of agro-waste: techno-economic assessment of full scale applications. J. Environ. Manage. 216, 111-119 (2018)

16. Huber Solar Active Dryer SRT. http://www.huber.de/products/ sludge-treatment/sludge-drying/huber-solaractive-dryer-srt. html. Accessed Jan 2019

17. Decreto Legislativo 29 aprile 2010, n.75: Riordino e revisione della disciplina in materia di fertilizzanti, a norma dell' articolo 13 della legge 7 luglio 2009, n. 88. In: Gazzetta Ufficiale 121 del 26 maggio 2010

18. Average temperature along the year in Verona, Italy. In: Wikipedia. http://en.wikipedia.org/wiki/Verone. Accessed Jan 2019

19. APHA/AWWA/WEF: Standards Methods for the Examination of Water and Wastewater, 20th edn. United Book Press, Inc., Baltimore (1998)

20. Ukwuani, A.T., Tao, W.: Developing a vacuum thermal stripping e acid absorption process for ammonia recovery from anaerobic digester effluent. Water Res. 106, 108-115 (2016)

21. Wu, C., Yu, M., Huang, Q., Ma, H., Gao, M., Wang, Q., Sakai, K.: Stimulation of methane yield rate from food waste by aerobic pre-treatment. Bioresour. Technol. 261, 279-287 (2018)

22. Fernandez-Bayo, J.D., Yazdani, R., Simmons, C.W., Vander Gheynst, J.S.: Comparison of thermophilic anaerobic and aerobic treatment processes for stabilization of green and food wastes and production of soil amendments. J. Environ. Manage. 169, 293-302 (2018)

23. Teglia, C., Tremier, A., Martel, J.L.: Characterization of solid digestates: part 1, review of existing indicators to assess solid digestates agricultural use. Waste Biomass Valorization 2, 43-58 (2011)

24. Strazzera, G., Battista, F., Garcia, N.H., Frison, N., Bolzonella, D.: Volatile fatty acids production from food wastes for biorefinery platforms: a review. J. Environ. Manage. 226, 278-288 (2018)

25. Tampone, F., Genevini, P., D'Imporzano, G., Adani, F.: Assessing amendments properties of digestate by studying the organic matter composition and the degree of biological stability during the 
anaerobic digestion of the organic fraction of MSW. Bioresour. Technol. 100(12), 3140-3142 (2009)

26. Hu, Z., Houweling, D., Dold, P.: Biological nutrient removal in municipal wastewater treatment: new directions in sustainability. J. Environ. Eng. 138, 307-317 (2012)

27. Montejo, C., Costa, C., Marquez, M.C.: Influence of input material and operational performance on the physical and chemical properties of MSW compost. J. Environ. Manage. 162, 240-249 (2015)

28. Characterisation end products of biological treatment, Report. Flemish Compost Agency (Vlaco), Mechelen, Belgium (2012)

29. Kirchmann, H., Bernal, M.P.: Organic wastes treatment and C stabilization efficiency. Soil Biol. Biochem. 29, 1747-1753 (1997)

30. Liu, Y., Lai, N.W., Gao, K., Chen, F.J., Yuan, L.X., Mi, G.H.: Ammonium inhibits primary root growth by reducing the length of meristem and elongation zone and decreasing elemental expansion rate in root apex of Arabidopsis thaliana. PLoS ONE 8, 1-11 (2013)

31. Battista, F., Fino, D., Erriquens, F., Mancini, G., Ruggeri, B.: Scaled-up experimental biogas production from two agro-food waste mixtures having high inhibitory compound concentrations. Renew. Energy 81, 71-77 (2015)

32. Stabenau, N., Zehnsdorf, A., Rönicke, H., Wedwitschka, H., Moeller, L., Ibrahim, B., Stinner, W.: A potential phosphorous fertilizer for organic farming: recovery of phosphorous resources in the course of bioenergy production through anaerobic digestion of aquatic macrophytes. Energy Sustain. Soc. 8, 16-25 (2018)
33. Zhao, Q.B., Ma, J., Zeb, I., Yu, L., Chen, S., Zheng, Y.M., Frear, C.: Ammonia recovery from anaerobic digester effluent through direct aeration. Chem. Eng. J. 279, 31-37 (2015)

34. Green, D.W., Perry, R.H.: Perry's Chemical Engineers' Handbook. 8th ed. McGraw-Hill, New York (2007)

35. Average temperature along the year in Sfax, Tunisia. In: Wikipedia. https://en.wikipedia.org/wiki/Sfax. Accessed Jan 2019

36. Quina, M.J., Lopes, D.V., Cruz, L.G., Andrade, J., Martins, R.C., Gando-Ferreira, L.M., Dias-Ferreira, C., Quinta-Ferreira, R.M.: Studies on the chemical stabilisation of digestate from mechanically recovered organic fraction of municipal solid waste. Waste Biomass Valorization 6, 711-721 (2015)

37. Gontard, N., Sonesson, U., Birkved, M., Majone, M., Bolzonella, D., Celli, A., Angellier-Coussy, H., Jang, G.W., Verniquet, A., Broeze, J., Schaer, B., Batista, A.P., Sebok, A.: A research challenge vision regarding management of agricultural waste in a circular bio-based economy. Crit. Rev. Environ. Sci. Technol. 48(6), 614-654 (2018)

Publisher's Note Springer Nature remains neutral with regard to jurisdictional claims in published maps and institutional affiliations. 